DOI: https://doi.org/10.51209/platform.2.4.2021.131-163

УДК 7.03; 7:001.12

Ольга Николаевна ФИЛИППОВА, заведующая архивом, Политехнический музей,

Москва, Россия, e-mail: iscusstvo0891@mail.ru, ORCID: 0000-0002-8933-1214

\title{
ЖИВОПИСНЫЙ ДАР НИКОЛАЯ САПУНОВА И ТЕАТР
}

Аннотация. Студия на Поварской (Театр-студия на Поварской), возникшая при Московском Художественном театре, была создана в мае 1905 г. усилиями одного из его руководителей, К.С. Станиславским, и актером В.Э. Мейерхольдом. Н.Н. Сапунов, как нельзя более, был уместен в новой Студии, которая нравилась ему своими постановочными идеями и планами, намеченным репертуаром, в котором главная роль отводилась драматургам - неоромантикам и символистам, поисками новых форм для его сценического осуществления, стремлением к созданию новых принципов театрального искусства. После закрытия студии в октябре того же года, В.Э. Мейерхольд получил приглашение от В.Ф. Комиссаржевской работать в ее театре, который стал центром притяжения новых сил русской культуры. Это предложение было принято режиссером. В.Ф. Комиссаржевскую и В.Э. Мейерхольда объединяло огромное желание прекратить со сценическим бытовизмом и натурализмом, обрести новые театральные формы. Такому мастеру, как В.Э. Мейерхольд, обладавшему удивительным даром зрительно-пластического видения спектакля, нужна была на сцене выразительность настоящей живописи. В театр В.Ф. Комиссаржевской он привлек молодых художников, Н.Н. Сапунова, С.Ю. Судейкина, Б.И. Анисфельда, и не принадлежавшего к этому кругу, но близкого им, 
В.И. Денисова. Талантливые живописцы, эти молодые мастера были неопытны в вопросах сценической техники, разрешения пространственных задач. Но это и не требовалось В.Э. Мейерхольду. Он освободил декораторов от кропотливой и тщательной работы с макетом и ориентировал их на решение спектакля в чисто живописном плане. В мейерхольдовский период, который длился с 1906 по 1907 гг., в театре В.Ф. Комиссаржевской ведущими художниками были неразлучные друзья Н.Н. Сапунов и С.Ю. Судейкин - ученики К.А. Коровина. В их сценической живописи возникали образы символистской поэтики с ее недосказанностью, туманными грезами и призрачной мечтательностью. Она становилась невесомой, воздушно легкой либо декоративно острой, возбуждающей, построенной на неожиданных сочетаниях изысканных колористических созвучий цвета. В данной публикации автор, основываясь на изучении архивных и библиографических источников, анализирует живопись Н.Н. Сапунова, которая поражает своей удивительной красотой и гармонией, неизбывной декоративной фантазией. Мастер был способен, уйдя от натуры, преображать все видимое, - природу, предметы, - в мир красоты, волнующей, манящей, одушевленной и порою таинственной. Прослеживается творческий путь Н.Н. Сапунова, в таланте которого с его неисчерпаемой декоративностью В.Э. Мейерхольд распознал еще одну особенность дарования мастера - острую ироничность гротескного видения.

Ключевые слова: мастерская, живописное дарование, пейзаж, этюд, журнал, автобиография, символизм, модерн, выставки, театральные декорации и костюмы

Вступление. Неотъемлемой частью культурной жизни России рубежа XIX-XX вв. стали имена В. Брюсова, А. Белого, А. Блока, М. Врубеля, В. Борисова-Мусатова, В. Мейерхольда, В. Комиссаржевской, а также М. Метерлинка, Г. Ибсена, P. Вагнера. Дополнением к этой картине могут служить 
появлявшиеся друг за другом толстые символистские журналы «Весы» (1904-1909 гг.), «Искусство» (1905 г.), «Золотое Руно» (1906-1909 гг.), активно пропагандирующие символистский метод творчества, многообразная деятельность «Мира искусства», ориентированная на широкие контакты с Западом, и эпатажные выступления «Голубой Розы» [5, с. 16]. Это было время, когда менялось все и вся - художественное мышление, эстетические принципы, система художественного образования, когда искусство формировало в себе сознание главной движущей силы общества.

Николай Николаевич Сапунов оказался в эпицентре этих перемен. Он был их участником. Его чуткая, одаренная натура остро воспринимала происходящее, складывалась под его воздействием и влиянием, но при этом все это сразу же приобретало его собственные черты, наделялось его энергетикой и преобразовывалось в яркое индивидуальное явление, носившее имя «Н.Н. Сапунов». Творческие истоки Н.Н. Сапунова - это пленэрная живопись И.И. Левитана, импрессионизм К.А. Коровина. Далее он развивался по пути, предначертанному закономерностями развития живописи начала XX в. Он стал постимпрессионистом, приобщился отчасти к символизму, модерну, экспрессионизму. Но его путь обладал своеобразием, присущим русской культуре, духовному, психическому складу народа, его художественного дара. Творческие склонности связали Н.Н. Сапунова со многими его сверстниками и соучениками по Училищу живописи, ваяния и зодчества в одну творческую группу, создавшую художественное направление «Голубая роза», в организации которой Н.Н. Сапунов принял самое деятельное участие [8, c. 175].

Постановка проблемы. Театр, творчество в котором было связано с такими крупными режиссерами-новаторами, как В.Э. Мейерхольд и Ф.Ф. Комиссаржевский, очень сильно привлекал Н.Н. Сапунова. Творческая деятельность в сфере театрально-декорационной живописи, даже при исполнении чужого замысла, позволяла выразиться его живописному дару, 
реализовать художнический темперамент, размахнувшись на больших плоскостях. К тому же работа декоратора давала средства к существованию. Все это Н.Н. Сапунову обещала связь с возникшим весной 1905 г. «Театром трагедий», организованным артистом Художественно-Общедоступного театра Н.Н. Вашкевичем, который видел смысл своей постановочной деятельности в воплощении душевной красоты человека и утверждении его способности к духовному преображению с помощью искусства [8, с. 37]. Во всем этом была совершенно очевидна перекличка с идеями синестезии французских символистов, утверждавших родство звука, цвета, запаха.

Этими идеями были освещены творческие усилия в одной из первых лирических символистских драм К.Д. Бальмонта «Три расцвета» (1904 р.), которую оформлял Н.Н. Сапунов [8, с. 37].

Анализ последних исследований и публикаций. Жизни и творчеству Н.Н. Сапунова посвящено много исследований. Он и сам вел дневники, которые не были опубликованы. Так, Д.З. Коган, автор книги «Николай Николаевич Сапунов: 1880-1912», ссылается на тетрадь Н.Н. Сапунова с черновиками писем к В.Э. Мейерхольду, Ф.Ф. Комиссаржевскому, М.А. Кузмину и другим лицам, которая сейчас хранится в Отделе рукописей Государственной Третьяковской галереи и датируется примерно 1907 г. [8, с. 139]. Слова из тетради Н.Н. Сапунова: «... театральная декорация только тогда хороша, когда она передает дух и стиль известного драматического произведения... и чем лучше сливается декорация с драматическим произведением, тем сильнее, конечно, выигрывает вся постановка. Словом, автор, режиссер и живописец должны говорить одним языком. Это, кажется, так просто, но, к сожалению, почти никто этого не понимает. Мне кажется, что уже проходит то время, когда декорации были приятным фоном», - были очень созвучны мыслям и высказываниям об искусстве театра 
Ф.Ф. Комиссаржевского, с которым Н.Н. Сапунов не прерывал отношений очень долгие годы [8, с. 139]. Идея гармонии искусств в спектакле, захватившая Ф.Ф. Комиссаржевского и Н.Н. Сапунова, имела прочные национальные традиции. Она начала формироваться на домашней сцене С.И. Мамонтова, а затем получила выражение в его Частной опере. Там складывались такие идеи, в частности, в творческом сознании К.А. Коровина, с которым непосредственно сотрудничал Н.Н. Сапунов, от которого он мог ими заразиться. Константин Алексеевич относился внимательно и участливо к своим ученикам, помогал им встать на ноги, быть самостоятельными художниками во всех областях живописного искусства. Об этом мы можем подробно прочитать в его письмах, документах, воспоминаниях: «Константин Коровин. Жизнь и творчество» [10].

Нельзя снова не отметить, говоря о Н.Н. Сапунове, большого вклада в изучение его творчества, сделанного Д.З. Коган, по материалам которой посмертно в 1998 г. была издана ее последняя книга о художнике, явившаяся первой монографией о Н.Н. Сапунове (начало подготовки этой книги к изданию было положено еще в 1993 г.). Исследовательница провела большую работу по сбору произведений и анализу творческого наследия художника. Однако в силу ряда обстоятельств упомянутое издание ни полиграфически, ни по уровню научной обработки материала не соответствует масштабу личности художника и не может дать достаточного представления о живописном мастерстве Н.Н. Сапунова, вследствие чего не полностью решает задачи исследования его творчества. Книга И.М. Гофман «Николай Сапунов» - это первый подход к систематизации обширного, несмотря на краткость деятельности, творческого наследия Н.Н. Сапунова [5, с. 11]. Оно было весьма разбросано, и помимо большого числа экспонировавшихся на выставках произведений, хранящихся в музеях и известных частных коллекциях, имеется множество неучтенных эскизов и набросков. Впервые в данном издании публикуется личный 
архив художника, в котором содержатся его заметки об искусстве, черновики писем, замыслы различных тем и множество рисунков натурного и подготовительного характера. В книгу были также включены материалы сборника воспоминаний современников о художнике и посвящений ему. Сборник явился откликом на трагическую гибель Н.Н. Сапунова в 1912 г., вышел в 1916 г. и отныне стал библиографической редкостью.

Цель данной публикации - раскрыть редкий живописный дар Николая Сапунова как театрального художника и декоратора, сформированного эпохой, проанализировать его работы.

Изложение основного материалы. Николай Николаевич Сапунов родился 17 декабря 1880 г. в Москве, на Шаболовке, в небогатой купеческой семье. Сапуновы жили в доме, окруженном большим садом. Его отец имел свечной завод, где отливались вручную престольные свечи, которые затем раскрашивались, украшались лепным орнаментом, причем яркие цвета окраски усиливались обильной позолотой.

Помимо завода, источником дохода для семьи Сапуновых служили и обширные оранжереи, где выращивались цветы для продажи. Конечно же, красочные впечатления не могли не оставить следа в душе ребенка. Видимо, и у маленького Николая, и у его брата Клавдия желание стать художниками появилось очень рано. Во всяком случае, оба они со временем поступили в Московское училище живописи, ваяния и зодчества. Николай подал прошение туда в 1893 г., а в 1898 г. в Училище руководить пейзажным классом пришел И.И. Левитан, и Н.Н. Сапунов поступил в его мастерскую. Выдающееся живописное дарование Н.Н. Сапунова проявилось очень рано. Уже в 1900 г. он получил официальное признание, когда его пейзаж «Зима» $(1900$ г.) был принят на XXVIII передвижной выставке (сейчас этот пейзаж находится в Государственной Третьяковской галерее) [6, с. 1] (рис. 1). Картина, изображающая Нарышкинский сквер на Страстной (ныне Пушкинской) площади в Москве, была встречена с 
одобрением не только передвижниками, еще сохранявшими в те годы господствующее положение в русской живописи, но и представителями недавно возникшего течения «Мир искусства» $[6$, c.1]. Об успехе Н.Н. Сапунова у молодой школы говорит то обстоятельство, что его «Зима» была воспроизведена в журнале «Мир искусства» за 1900 г. (№ 9-10, с.114) [6, с. 1].

Написанный в серо-серебристой гамме, хорошо передающей состояние природы, этот пейзаж невольно напоминает известное произведение К.А. Коровина, входившего в основное ядро общества художников «Мир искусства» «Зимой» (1894 г.) [11, с. 4]. Колористические находки К.А. Коровина, который с 1901 г. вместе с В.А. Серовым начал вести в Московском училище живописи, ваяния и зодчества портретно-жанровую мастерскую, были ему особенно близки. Только в отличие от работы К.А. Коровина, пейзаж Н.Н. Сапунова был довольно большим по размеру, что выдает желание, видимо, внушенное ему И.И. Левитаном, написать именно картину, а не этюд.

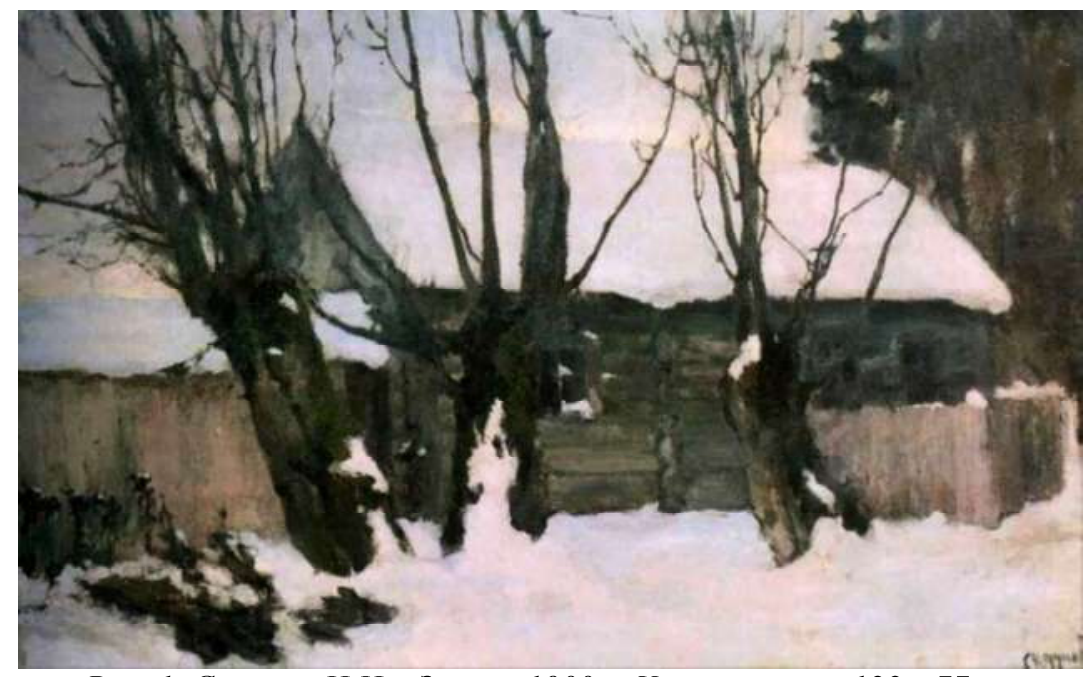

Рис. 1. Сапунов Н.Н. «Зима». 1900 г. Холст, масло. $122 x 77 \mathrm{cм.}$ Государственная Третьяковская галерея. Москва, Россия 
Однако, несмотря на большие размеры, подлинной картинности в произведении явно не получилось. Но в «Зиме» Н.Н. Сапунова все же сказались некоторые особенности живописи художника, которые разовьются впоследствии, - это стремление выдвигать изображаемое на ближний план, подчеркивание плоскости холста $[11$, с. 5]. Следует отметить, что и у К.А. Коровина в его упомянутом зимнем пейзаже все было сосредоточено на ближнем плане, но он не был замкнут строениями так, как у Н.Н. Сапунова. Будучи еще студентом, Н.Н. Сапунов, по рекомендации И.И. Левитана, стал работать в декорационных мастерских Московского Художественного театра у художника и сценографа В.А. Симова (именно в данный период разорился и вскоре умер отец художника, и вся семья оказалась в очень затруднительном положении). В.А. Симов осуществлял почти все постановки театра, но работа в мастерских не могла устроить Н.Н. Сапунова. Здесь он был всего лишь исполнителем чужих замыслов. В 1901 г. Н.Н. Сапунов весной окончил Училище живописи, ваяния и зодчества с получением серебряной медали и званием неклассного художника. Именно там с 1902 г. он решает продолжить свое художественное образование. Именно в мастерской В.А. Серова и К.А. Коровина произошло и его сближение с товарищами по училищу: А.А. Араповым, В.В. Каревым, П.В. Кузнецовым, А.Т. Матвеевым, К.С. Петровым-Водкиным, М.С. Сарьяном, С.Ю. Судейкиным, Н.П. Ульяновым, П.С. Уткиным, Н.П. Феофилактовым (о чем впоследствии писал в своей автобиографии П.В. Кузнецов)» [11, c. 5].

Многие из этих художников затем составят вместе с Н.Н. Сапуновым основу выставок «Алая роза» и «Голубая роза» $[11$, c.5]. В 1901-1903 гг. Н.Н. Сапунов вместе с П.В. Кузнецовым работал подмастерьем в мастерских Большого театра под руководством К.А. Коровина, который дал им возможность осуществить самостоятельно в 1902 г. оформление «Валькирии» Рихарда Вагнера [11, с. 5]. 
Как вспоминал потом П.В. Кузнецов, постановка очень удалась: «Константин Алексеевич ходил довольный на спектакле, а мы были бесконечны благодарны ему за его отеческую заботу о нас» [10, с.268]. На рубеже 1900-х гг. произошло еще одно очень важное событие в жизни Н.Н. Сапунова - он познакомился с С.И. Мамонтовым. Возможно, что это произошло не без участия П.В. Кузнецова. Можно только предположить, что настоящее сближение Сапунова и Мамонтова относится к началу 1900-х гг., к периоду, когда, уже будучи разоренным, Савва Иванович, тем не менее, основал в 1896 г. в Москве за Бутырской заставой керамический завод «Абрамцево» и пробовал создать оперу в Каретном ряду в Эрмитаже [11, с.5]. Случилось ли это до или после двухмесячной поездки Н.Н. Сапунова в Италию в 1902 г. вместе с товарищами по училищу, будущим архитектором В.M. Маятом и художником М.А. Демьяновым (они побывали в Риме, Флоренции, Пизе и после многочисленных перипетий, связанных, в основном, с безденежьем, вернулись на родину), пока неизвестно. Судя по анкете-биографии Н.Н. Сапунова, составленной для Государственной Академии художественных наук по воспоминаниям К.В. Кандаурова, П.В. Кузнецова, А.А. Арапова и М.А. Кузмина, в Италии пробудилась любовь Н.Н. Сапунова к Боттичелли и Мантенье. А также к примитивам и к миниатюре. Итальянские впечатления, безусловно, дали о себе знать в эскизе декорации к опере Кристофа Виллибальда Глюка «Орфей», шедшей в театре «Эрмитаж» в сезон 19021903 г. [11, с. 6] (рис. 2). 




Рис. 2. Сапунов Н.Н. Эскиз декораиии к опере К.В. Глюка «Орфей». Начало 1900-х г2. Холст, масло. 50,5 х 81,5 cм.

Государственный центральный театральный музей имени А.А. Бахрушина. Москва, Россия

О них напоминает, в частности, и мраморный жертвенник, и классический портик в центре композиции, и вытянутая по пропорциям фигура в античной одежде. Здесь уже налицо и символическое начало, проявляющееся в туманной, дематериализованной атмосфере, и стиль модерн, выдающий себя в уплощенности форм. Характерной особенностью зрелого Н.Н. Сапунова станет трагическое мироощущение. От него он будет уходить в мир мечты или сказки, поэзию которой художник впервые раскрыл в декорациях к опере «Гензель и Гретель» Энгельберта Гумпердинка [11, с. 7] (рис. 3).

Эта опера шла в сезоне 1902-1903 г. в театре Эрмитаж, как и «Орфей» Глюка [11, с. 7]. Работы Н.Н. Сапунова, именуемые эскизами декораций к опере «Гензель и Гретель», датируются его биографом Е.О. Гунстом 1904 г. [11, с. 7]. Но, если это действительно так, то можно считать, что уже в это 
время художник пишет свои театральные произведения не до, а после спектакля.

На самом деле это не эскизы декораций, а картины, в которых «мы всегда видим не просто место действия, а его определенный момент действия и в большинстве случаев кульминационный» $[11$, с. 7]. В работах нас поражает прежде всего удивительная слаженность тонов, возможно, что это тоже результат влияния К.А. Коровина. Однако мозаичность мазков вместе с романтичностью общего настроения вызывает в памяти образы М.А. Врубеля, который, кстати сказать, в 1895 г. оформлял эту оперу на сцене Частной оперы С.И. Мамонтова. Но живописное напряжение, свойственное искусству М.А. Врубеля, сменяется у Н.Н. Сапунова легкой невесомостью

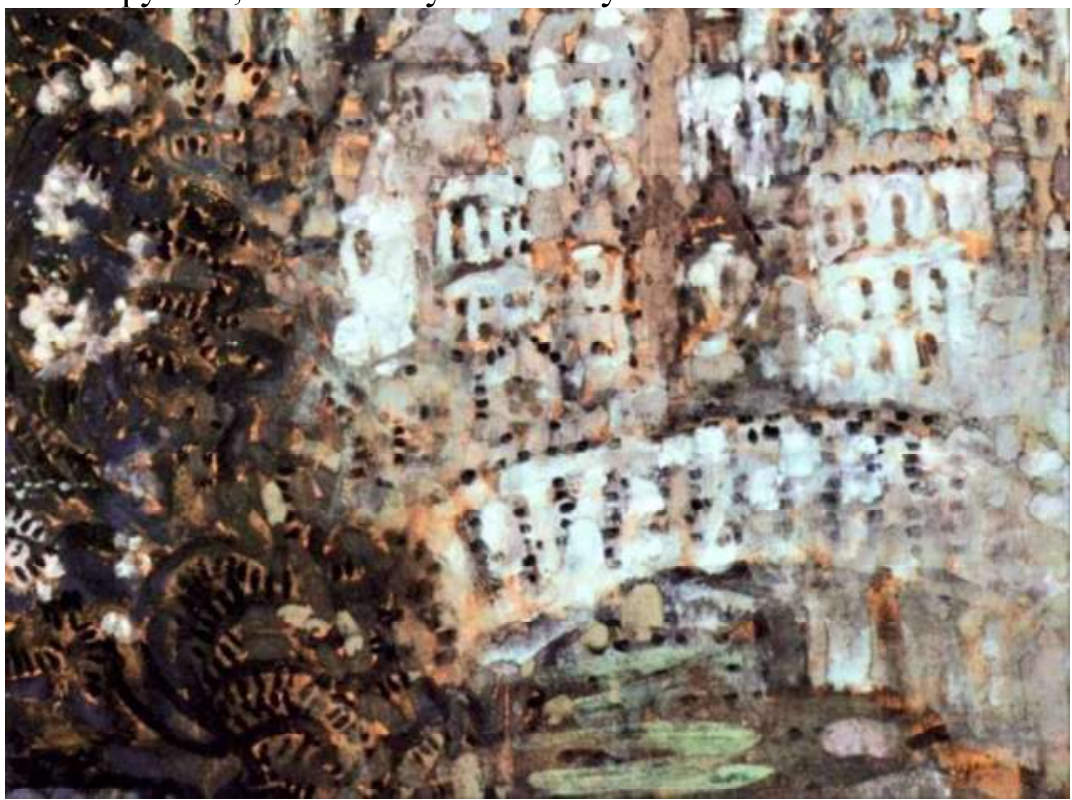

Рис 3. Сапунов Н.Н. Эскиз декорачии к опере Э. Гумпердинка «Гензель и Гретель». Начало 1900-х г2. Бумага, темпера. $64 x$ 77,3 см.

Государственный чентральный театральный музей имени А.А. Бахрушина. Москва, Россия 
бархатистой фактуры, создающейся клеевой темперой, техникой, которая будет особенно любима художником.

В данном случае она помогает создать образы, исполненные гармонической лиричности. Вместе с тем фантастичность сказочного мира, момент некоторой недосказанности этих театральных работ говорит о близости Н.Н. Сапунова к символизму. В тоже время тяготение к определенной плоскостности пластического решения говорит об использовании стилистики модерна, который наиболее соответствовал передаче символистских настроений.

Помимо работы в театре для С.И. Мамонтова, Н.Н. Сапунов трудился у него и на Гончарном заводе за Бутырской заставой. Именно там было выполнено майоликовое панно для дома М.В. Сокол (1901-1902 гг.), в котором Н.Н. Сапунов изобразил летящего над пучиной вод сокола, тем самым намекая на фамилию владелицы здания, созданного по проекту видного представителя модерна, архитектора И.П. Машкова.

Н.Н. Сапунов удачно выбрал голубые и синие тона для неба, особенно хорошо смотревшиеся в ясные дни. Панно придавало зданию нарядный характер и благодаря декоративности цвета подчеркивало некую сказочность в, казалось бы, прозаическом сооружении - доходном доме. Историк архитектуры М.В. Нащокина связывает с именем Н.Н. Сапунова и изразец, хранящийся в собрании Московского государственного университета инженерной экологии (1900-е гг.). Здесь изображен растительный мотив - деревья над водой, заросли камыша и листья кувшинок, излюбленный для символизма и модерна, намекающий о тайнах подводного мира. Красив золотистый тон этого изразца, словно передающий золото солнечного летнего дня. Весной 1905 г. возник «Театр трагедий», организованный артистом ХудожественноОбщедоступного театра Н.Н. Вашкевичем [8, с. 37]. Связь с ним давала средства к существованию Н.Н. Сапунова как декоратора. Оформление «Трех расцветов» К.Д. Бальмонта представляет нам их автора увлеченным экспериментатором в 
области стиля модерн и достойным участником борьбы за его становление и укоренение в России [8, с. 37]. Хотя его произведения не выразили эту стилистику в достаточно определенной форме, а лишь подступали к ней (вернее, следовало бы их определить как примеры предмодерна), они примечательны для характеристики начала творческого пути Н.Н. Сапунова. В мае 1905 г. усилиями одного из руководителей Московского Художественного театра, К.С. Станиславского, и актера В.Э. Мейерхольда была создана студия на Поварской. В поисках новых театральных форм К.С. Станиславский задумал превратить свою студию в экспериментальную мастерскую.

Он привлек к работе в ней молодежь В.Э. Мейерхольда, Н.Н. Сапунова и начинавшего тогда свою театральную деятельность художника С.Ю. Судейкина, которого называли наследником и преемником Н.Н. Сапунова. Постановщики применили здесь новый прием: вместо обычных трех стен на сцене был только один задний занавес, на фоне которого и развертывалось действие.

Новизна декораций Н.Н. Сапунова и С.Ю. Судейкина заключалась также и в том, что они отказались от обычных эскизов, по которым помощники художника выполняют декорации (они сами писали их). Однако новаторские приемы молодых энтузиастов показались К.С. Станиславскому чересчур рискованными, и постановка пьесы Мориса Метерлинка «Смерть Тентажиля» (год создания этой пьесы для театра марионеток - 1894 г.) так и не была показана публике [6, с. 2]. По-видимому, в том, что постановка не состоялась, были виноваты все же не художники, как это принято считать. В.Я. Брюсов писал о постановке «Смерти Тентажиля»: «В общем, то был один из интереснейших спектаклей, какие я видел в жизни, но все же я вынес убеждение, что устроители не понимали сами, чего они искали...» [8, с. 43]. Уже к этому времени Н.Н. Сапунов превращается в оригинального мастера, которому были доступны разные области изобразительного искусства. Однако в 
1903-1904 учебном году он подал прошение в Совет преподавателей Московского училища живописи, ваяния и зодчества с просьбой продлить его пребывание там на год. Видимо, эта просьба была связана с нежеланием проходить после окончания училища военную службу, и, когда ему было отказано, но предложено написать картину для получения звания классного художника, он внезапно уехал в Петербург и поступил там в Академию художеств, в мастерскую А.А. Киселева (1904-1911 гг.), у которого ему, по сути, уже нечему было учиться. Поэтому вскоре Н.Н. Сапунов оформил отпуск и снова уехал в Москву, где его ждало участие в театральной жизни второй столицы. Представителем молодого художественного течения внутри символизма и модерна, которое было верно обозначено художником Б.Л. Липкиным, как «эмоционализм», основанный на возможностях цвета, передающего тонкие душевные движения, как и музыка, Н.Н. Сапунов осознавал себя после выступления в 1905 г. в Московском товариществе художников вместе с П.В. Кузнецовым, В.Д. Милиоти, С.Ю. Судейкиным, П.С. Уткиным и другими [11, с. 15]. Между 1905 и 1908 гг. Н.Н. Сапунов создает несколько картин, которые привлекают к нему большое внимание.

Художник увлекается воссозданием далекого прошлого: он пишет ряд полотен, на которых изображает ночные празднества, маскарады в старинных парках. Под высокими деревьями гуляют или танцуют нарядные дамы и кавалеры, сквозь ночной сумрак светятся разноцветные бумажные фонарики, все подернуто легкой прозрачной дымкой («Маскарад», 1907 г., Государственная Третьяковская галерея; «Ночной праздник», 1907 г., собрание А.Л. Мясникова) [6, с. 1] (рис. 4).

Для выставки и одноименного объединения «Голубая роза» (1907 р.) Н.Н. Сапунов выполнил обложку каталога, изобразив на ней нежно-голубой цветок, символ недостижимой, но прекрасной мечты, навеянный и образом романтика Новалиса, и стихотворением К.Д. Бальмонта, в котором голубая 
роза оказывается созданной из «блистающих вод», и потому ею невозможно завладеть [11, с. 15]. Возможно, что подобная роза чудится в струях фонтана, поставленного по центру композиции в представленной на выставке картины Н.Н. Сапунова «Маскарад» (1907г.) [11, с. 15]. Его обступают участники праздника. Их очертания неясны, они словно бы окутаны туманной пеленой (влияние В.Э. Борисова-Мусатова в этом приеме было очень очевидно) и тем самым видоизменены настолько, что нежные пятна их одежд были подобны звукам, льющимся в сумраке ночного парка.

Гирлянда огней, идущая параллельно толпе, - негромкие аккорды, как бы оживляющие гамму, как и фигурка в красном. Момент театрализации явно присутствует и в другой картине, бывшей на выставке «Голубая роза», - это «Балет» (1906 г.), где перед зрителем и сцена, и театральная ложа слева [11, с. 16] (рис. 5). В этой работе музыкальное начало подчеркнуто ритмами танцоров, хрупкость фигур которых уподобляет изображенное чему-то нереальному.

Своим изяществом и тонкой поэтичностью эти полотна напоминают картины Ватто. Вместе с тем в них сказывается увлеченность прошлым, которая овладела в те времена художниками из группы «Мир искусства» - К.А. Сомовым, А.Н. Бенуа, М.В. Добужинским и другими [6, с. 1]. В этих картинах Н.Н. Сапунова сказывается и еще одна присущая ему черта - сильное увлечение театром.

Действие разворачивается, как на подмостках, хотя композиция построена пространственно, здесь дана обычная перспектива. Среди других работ Н.Н. Сапунова, представленных на выставке «Голубая роза», был и натюрморт «Розы», и работы на тему «Балаганчика», в оформлении которого В.Э. Мейерхольду и Н.Н. Сапунову удалось словно воедино сплавить все художественные особенности поэтики пьесы $[11$, с. 16]. 


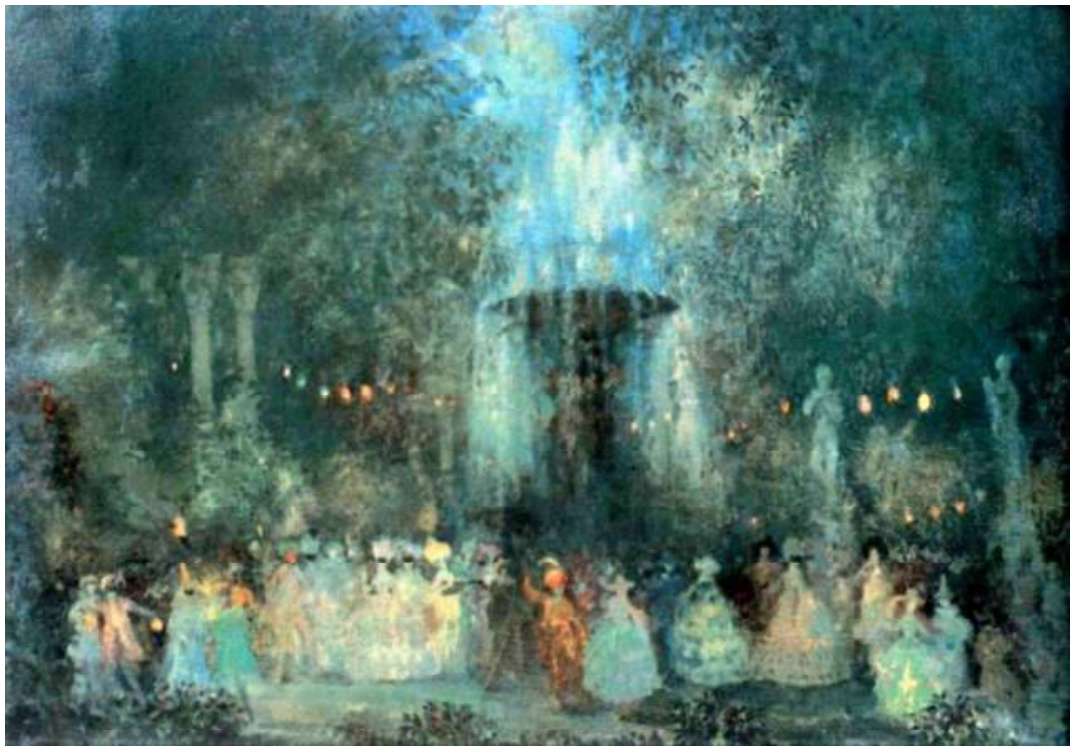

Рис. 4. Сапунов Н.Н. «Маскарад». 1907 г. Холст, масло. 93 х 64 см. Государственная Третьяковская галерея. Москва, Россия

Декорации к пьесе А.А. Блока «Балаганчик» явились следующим этапом в театральном творчестве Н.Н. Сапунова $[6$, c. 2]. Пьеса отражает глубокий кризис, который переживал в то время поэт. Разочаровавшись в символизме и в присущей этому течению мистике, А.А. Блок дает гротескное изображение собрания мистиков. Причем, оказывается, что мистики - это всего лишь манекены, в то время как персонажи, обычно воспринимаемые как вымышленные, условные театральные герои (Пьеро, Коломбина), наделены реальными человеческими чувствами. Пьеса давала художнику обильный материал для гротескного изображения жизни, и Н.Н. Сапунов создал зрелище, глубоко раскрывающее замысел поэта. На сцене была воздвигнута вторая сцена - с выступающей впереди суфлерской будкой; тем самым подчеркивалось, что все, что видит зритель, - лишь балаганчик, да и сама жизнь - такой же балаганчик, все в ней двойственно, все противоречиво, все мечты - призрачны и 


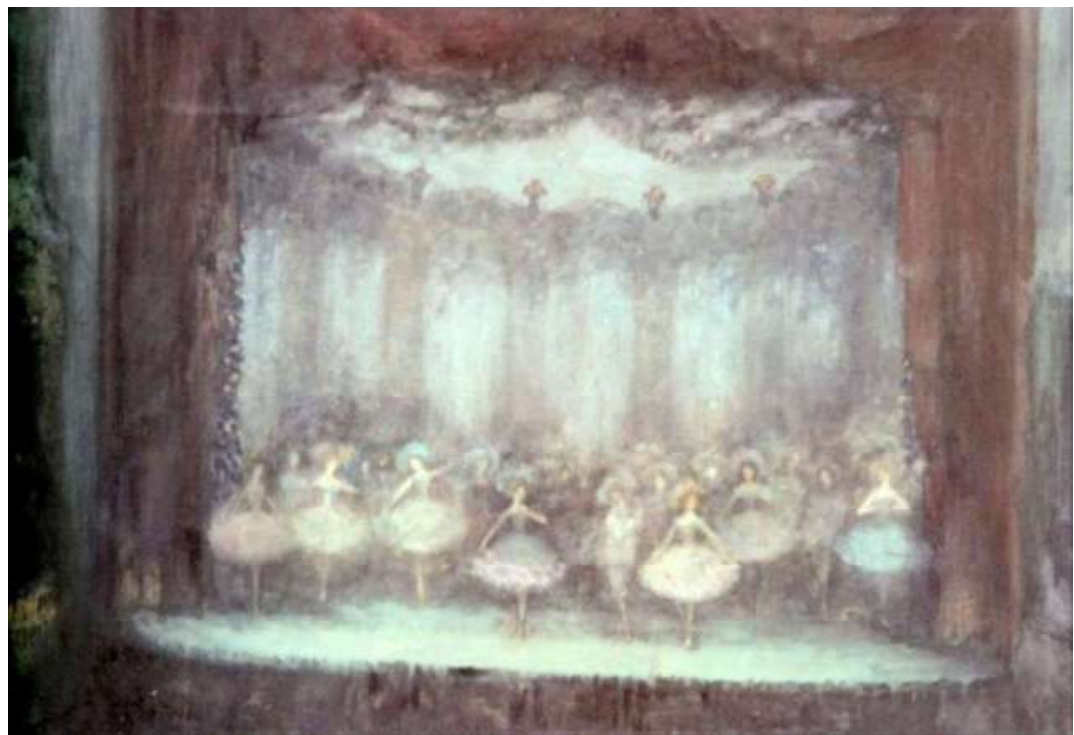

Рис. 5. Сапунов Н.Н. «Балет». 1906 г. Холст, масло. $102 x 69$ см. Государственная Третьяковская галерея Москва, Россия

неосуществимы, и, следовательно, нельзя относиться к жизни иначе, как с глубокой иронией. Постановка имела огромный успех. Следует отметить, что в этой постановке Н.Н. Сапунов впервые обращается к современной русской жизни: действие происходит в провинциальном городке, в комнате с простенькими аляповатыми обоями и самой обыденной мебелью, и, тем самым, подчеркивается контраст между заседающими, мысли которых направлены в потусторонний мир, и окружающей их мещанской обстановкой. Гротеск тут достигает крайней, преднамеренно подчеркнутой, остроты. Картина «Мистическое собрание. На сюжет лирической драмы 


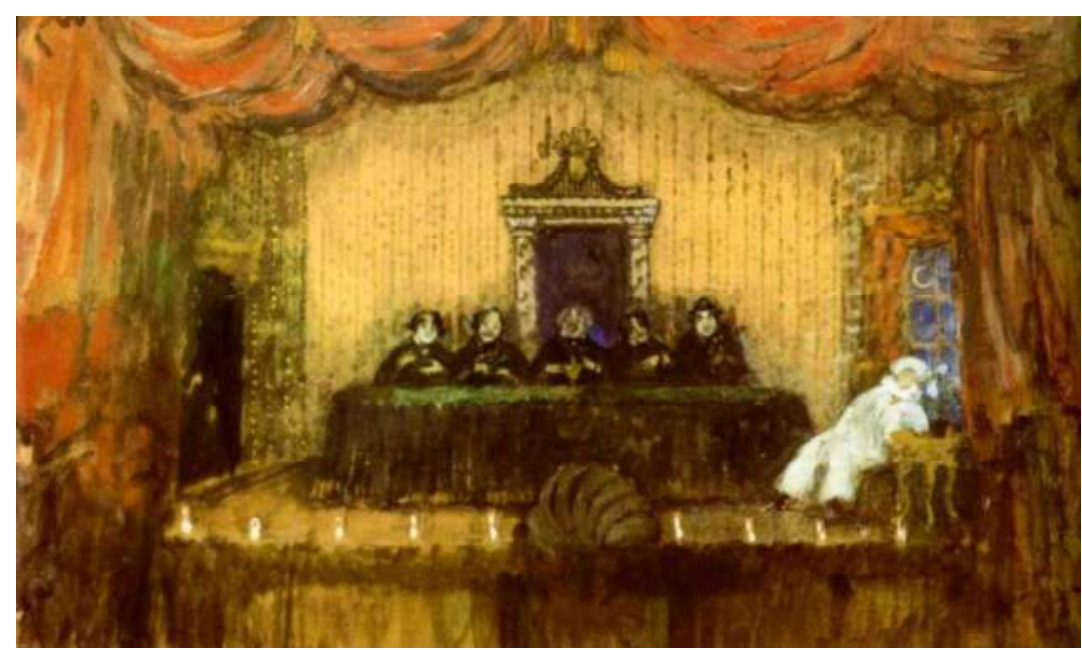

Рис. 6. Сапунов Н.Н. «Мистическое собрание. На сюжет лирической драмы А.А. Блока «Балаганчик»». 1907 г. Бумага, гуамь, бронза, золото, серебро, уголь. $42 x 84$ см. Государственная Третьяковская галерея. Москва, Россия

А.А. Блока «Балаганчик»» $(1907 \quad$ г., Государственная Третьяковская галерея) принадлежит к числу самых совершенных созданий живописца $[6$, с.2] (рис. 6). Большой успех Н.Н. Сапунова как театрального художника был связан с постановкой В.Э. Мейерхольдом пьесы Ибсена «Гедда Габлер» в 1906 г. в Театре В.Ф. Комиссаржевской в Петербурге [6, с.2]. Зрители были поражены своеобразием и великолепием созданной Н.Н. Сапуновым обстановки. Однако ее необычность и художественная изысканность дали повод для упреков, что внешнее оформление спектакля идет вразрез с замыслом драматурга. Героиня пьесы Ибсена страдает от мещанской ограниченности, царящей вокруг нее, а на сцене зритель видел отнюдь не мещанскую затхлость, отчего протест Гедды становится малоубедительным. В работе «Ряженые» (1908г.) видны лица ряженых, которые заглядывают в окно комнаты и пугают в ней женщину и мальчика (вполне возможно, что это произведение было создано по драме А.А. Блока, т.к. в 148 
последние годы художник и поэт много дружили, но упоминаний об этом в источниках не было найдено) [11, с.17] (рис. 7).

Здесь цвета уже не заряжены внутренним светом, как в работах, выставленных на выставке «Голубая роза» [11, с. 17]. Зеленоватые и красно-оранжевые одежды ряженых сталкиваются в каком-то зловещем контрасте, нарушая теплую охристо-коричневатую атмосферу интерьера, цвета которых аккумулируются в одежде дамы и мальчика.

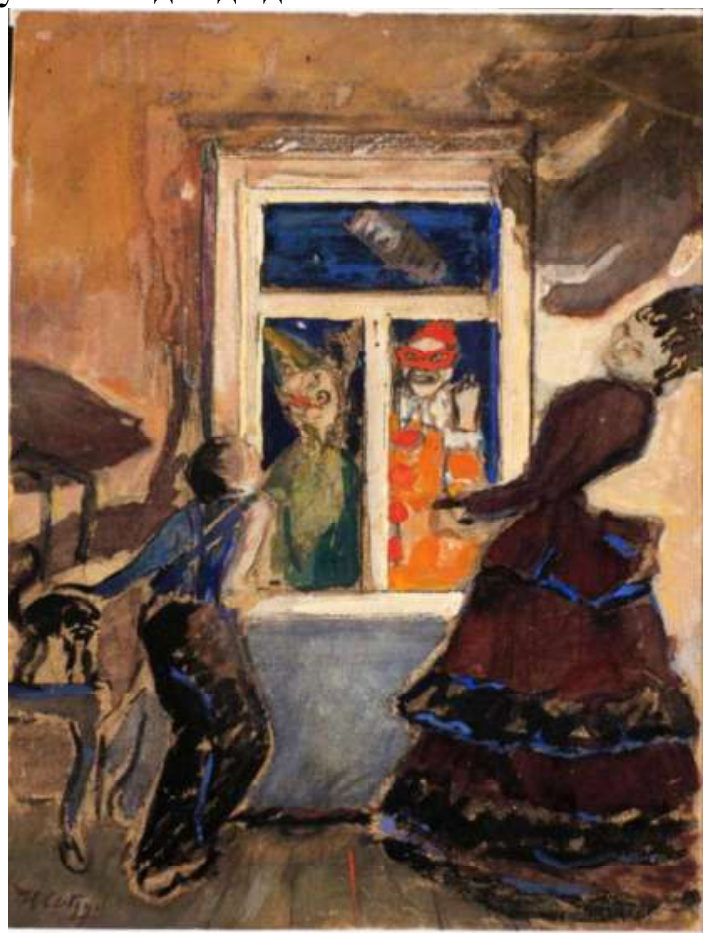

Рис. 7. Сапунов Н.Н. «Ряженые». 1908 г. Картон, бумага верже, гуашь, тушь, графитный карандаш, 36,5 Х 27,5 см. Государственная Третьяковская галерея. Москва, Россия

В этой работе есть некоторое предвестие трагического в восприятии жизни, как кошмара, экспрессионизма. И 
композиция акварели с веерообразным построением фигур вносит тревожную динамику в образ.

Нельзя не отметить, что в настроении этой работы есть нечто общее с произведением М.В. Добужинского «Окно парикмахерской» (1906 г.), где гримасы жизни олицетворяются тоже лицами, сатанински-уродливыми, и манекенами, как бы ожившими ночью при свете уличного фонаря, мимо которых спешит пройти прохожий [11, с.17] (рис. 8).

Помимо работы «Ряженые», важно также отметить серию «Балаганов» и «Каруселей», начатую художником в 1908 г. [11, с.17]. Лирическая тема раскрывалась и в живописной картине «Балаган», написанной в 1909 г., которая позволяет нам воссоздать оформление первого акта мейерхольдовской постановки. С 1910 г. Н.Н. Сапунов связал свою деятельность с Домом интермедий в Петербурге, став одним из его учредителей вместе с В.Э. Мейерхольдом и Н.В. Кузминым. Для Дома интермедий, основанного в 1910 г. в Петербурге по инициативе В.Э. Мейерхольда, Н.Н. Сапунов создал несколько декораций, в частности для двухактной пантомимы по А. Шницлеру «Шарф Коломбины» и для пасторали М.А. Кузмина «Голландка Лиза» (к «Голландке Лизе» - в соавторстве со своим другом художником, графиком, живописцем - А.А. Араповым) [6, с. 2] (рис. 9-10).

Вскоре обе пьесы были запечатлены Н.Н. Сапуновым в станковых картинах, одна из которых «Шарф Коломбины» - сейчас хранится в Театральном музее имени А.А. Бахрушина, а другая - «Голландка Лиза» - в Государственной Третьяковской галерее [6, с. 2].

В.Э. Мейерхольд и Н.Н. Сапунов трактовали «Шарф Коломбины», как трагический гротеск [6, с.2]. Приводим содержание пьесы, без знания которого трудно понять изображенное на картине. В день своей свадьбы с Арлекином легкомысленная Коломбина встречается с влюбленным в нее Пьеро и продолжает коварно уверять его в своей любви. Пьеро предлагает ей умереть вместе и первым принимает яд. Коломбина в ужасе убегает и присоединяется к друзьям, 
собравшимся на свадебный вечер. Начинается бал: пары кружатся в жутком танце, музыка подчеркивает зловещий характер происходящего. За окнами мелькает белое домино Пьеро. Коломбина не выдерживает и бежит к нему. Арлекин настигает еe возле мертвого соперника и убеждается, что Коломбина ему изменяла. Разгневанный, он уходит и запирает за собой дверь, оставив Коломбину наедине с мертвецом; девушка тщетно пытается вырваться.

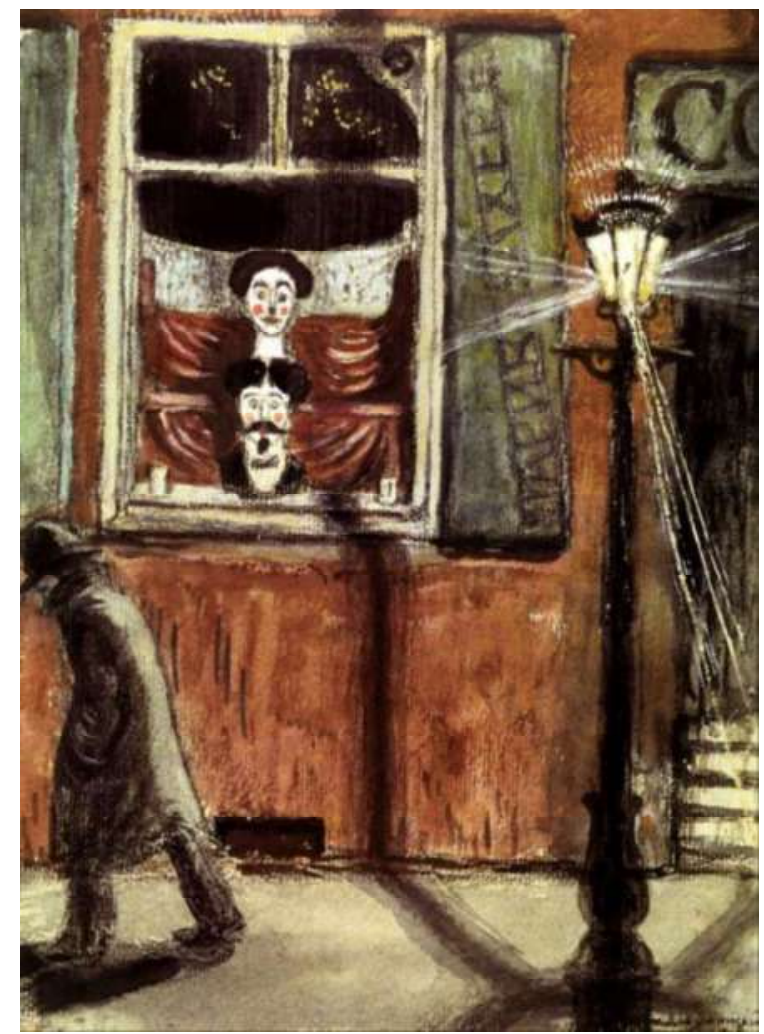

Рис. 8. Добужинский М.В. «Окно парикмахерской». 1906 г. Гуашь, акварель, уголь. 29,7х21,7 см. Государственная Третьяковская галерея. Москва, Россия 
Потрясенная случившимся, она выпивает остатки яда и падает мертвая возле Пьеро. Картина изображает тот момент, когда Арлекин, заметив исчезновение Коломбины, гневно выражает свое неудовольствие. Несмотря на трагическую ситуацию, свадебное веселье внешне продолжается - дирижер также неистово размахивает палочкой, музыканты старательно играют, а слуга-арапчонок обносит гостей фруктами. Но за всем этим чувствуется веяние смерти.

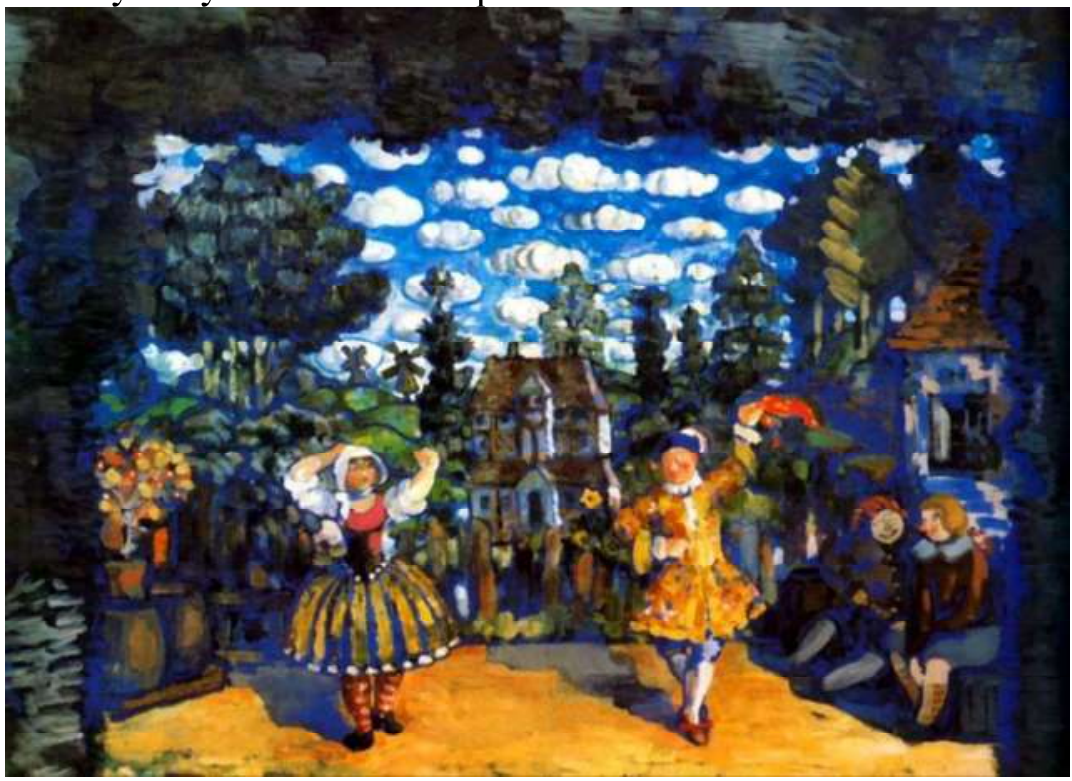

Рис. 9. Сапунов Н.Н. «Гостиница “Зеленый бык”». Эскиз декорачии к постановке пасторали М.А. Кузмина «Голландка Лиза». 1910 г. Картон, темпера, $103 x 73$ см. Государственная Третьяковская галерея. Москва, Россия

Трагизм происходящего особенно подчеркивается нелепостью окружающей обстановки и причудливостью персонажей. Н.Н. Сапунов добивается в этом особой остроты и трагичности. Гротеском иного рода, гротеском мягким, 
добродушным и веселым веет от другой картины - «Голландка Лиза» [6, с. 3]. Эта одноактная пастораль М.А. Кузмина написана в духе наивных старинных комедий. Лиза, дочь трактирщика, просватана за крестьянского паренька Луку.

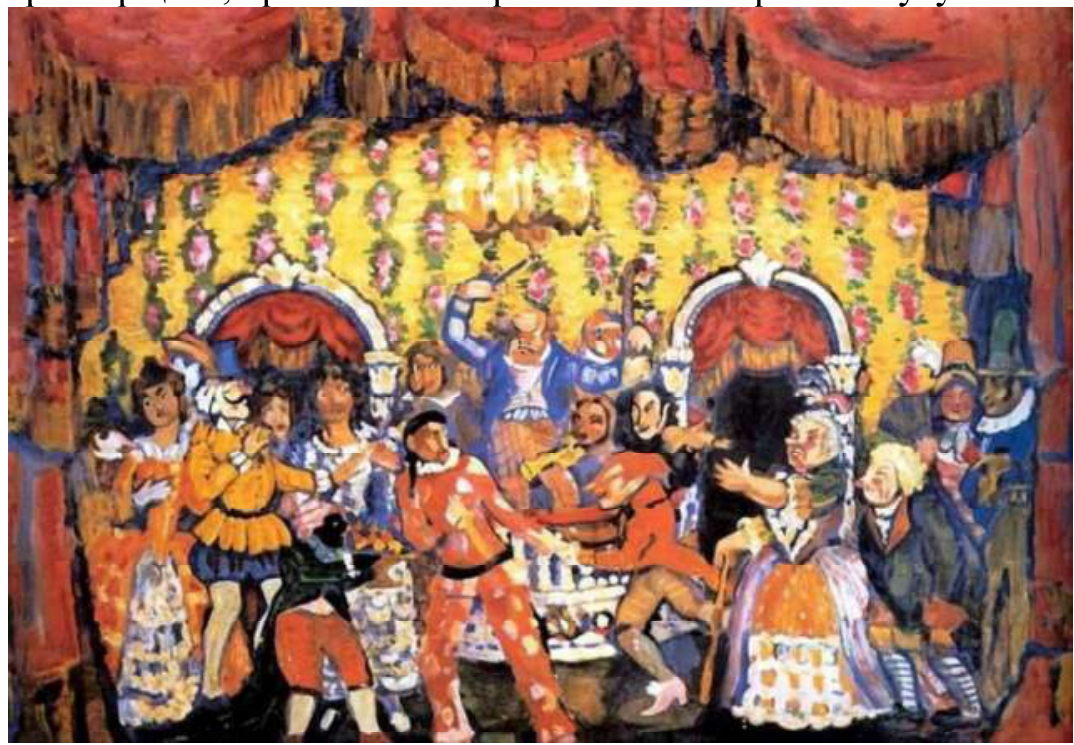

Рис 10. Сапунов Н.Н. «Шарф Коломбины». На сюжет рассказа А. Шниилера, в инсченировке В.Э. Мейерхольда». 1910 г. Картон, темпера. $107 \times 73,5$ см. Государственный чентральный театральный музей имени А.А. Бахрушина. Москва, Россия

Но вот в деревню к ним является, столичный артисттанцор, которого крестьяне принимают за вельможу. Лиза ему приглянулась, и сама она очарована его изяществом и танцами. Однако истинная любовь берет вверх, и Лиза остается верна своему жениху. Н.Н. Сапунов представил момент танца Лизы и незнакомца. В глубине виден замок, ветряные мельницы, курчавые деревья, справа - трактир «Зеленый бык» [6, с. 3]. Отец Лизы и ее жених, сидящие в густой тени, наблюдают, как Лиза танцует с «вельможей» [6, с. 3]. Облик кавалера полон выработанного, профессионального изящества, чего нельзя 
сказать о его толстоногой партнерше, хотя она и мила своей угловатой девичьей грацией. Обращает на себя внимание еще одна особенность театральных картин Н.Н. Сапунова - все они были обрамлены. Тем самым художник намеренно подчеркивает, что изображенное им - не реальная вещь, а театральное зрелище. В начале 1911 г., когда закрылся Дом интермедий, Н.Н. Сапунов решил работать с Ф.Ф. Комиссаржевским в театре К.Н. Незлобина в Москве. Его быт по-прежнему не был налажен. В Москве он жил у А.А. Арапова в доме инженера путей сообщения Петра Николаевича Перцова, но часто отъезжал в свою мастерскую в Петербург, а то и работал в мастерских своих товарищей.

Но больше всего он был увлечен замыслом Ф.Ф. Комиссаржевского создать на основе комедии-балета в пяти актах «Мещанина во дворянстве» или «Мещанинадворянина» (1911 г., театр К.Н. Незлобина, Москва) Мольера «балет в шести выходах, сопровожденный комедией», как это значилось еще в подзаголовке XVII в. [11, с. 39].

Современники по достоинству оценили «Мещанинадворянина», так он был назван постановщиками [11, с. 39]. И, конечно же, его успеху сопутствовали декорации и костюмы Н.Н. Сапунова. Существуют пять работ, созданных художником по этому спектаклю. Особенно хороши «Комната господина Журдена, Бал и Турецкая церемония» (все - 1911 г.) [11, c. 39]. В первом произведении Н.Н. Сапунов заставляет помещение экранами, сводит мебель до минимума, оставляя только около Журдена стул, похожий на трон.

Изысканные сине-голубые тона оттеняют до нелепости пышные оранжевые краски в костюме главного персонажа, усиленные еще зелеными букетами и красным камзолом слуги. Снова мастер использует в интерьере свое любимое сочетание синего с желтым, заставляя оба цвета звучать удивительно насыщенно, синий же при этом сообщает всему воздушность. В работе «Бал», напротив, преобладают красные тона в ковре на полу и в простенках между колоннами ротонды-зала [11, с. 39]. Здесь, кстати, больше, чем в других декорациях, сохранена 
конструкция сцены. И совершенно бесподобна по цветовым ритмам была «Турецкая церемония», где все фигуры организованы в симметричные группы, а в центре устремлен в небо фонтан, перекликающийся с облаками и своими динамичными струями словно усиливающий энергию танцующих персонажей $[11$, с. 39]. В сотрудничестве с Ф.Ф. Комиссаржевским Н.Н. Сапунов увлеченно работал и над костюмами, причем, Ф.Ф. Комиссаржевский подсказывал ему строение костюма XVII в., а Н.Н. Сапунов придавал каждому персонажу необходимую характерность, утрировал в целях выразительности цветовую характеристику, жест. Успех «Мещанина-дворянина» вдохновил художника на оформление в том же театре «Принцессы Турандот» (1912 г., театр К.Н. Незлобина) [11, с. 39]. Но художник успел выполнить только костюмы и эскизы занавеса и задника.

Спектакль был готов через три месяца после гибели Н.Н. Сапунова, и вся декорационная работа осуществлялась А.А. Араповым. Однако эскизы костюмов были очень выразительны. Достаточно взглянуть на два варианта костюма «Принцессы Турандот», чтобы убедиться, как цветом с преобладанием черного и лилового в первом эскизе и голубым с желтым - во втором художник добивается яркой зрелищности $[11$, c. 40$]$.

Причем, наряду с персонажами комедии дель арте в пьесе фигурировали китайские и турецкие персонажи. Н.Н. Сапунов специально изучал материальную культуру Востока, но смело преображал формы, стараясь избегнуть эклектичности, сделать сказку сказкой, где возможны совмещения стран и эпох. Однако в отсутствие Н.Н. Сапунова спектакль оказался лишенным цельности. Вот, что писал по этому поводу сам А.Н. Бенуа: «Н.Н. Сапунов был очень большим талантом и очень горячим художником, обожавшим свое дело и знавшим его глубоко... Столько красочности подлинной, радующей, стихийной в декорациях и костюмах и такое отсутствие ее в актерах! Получается что-то хромое и жалкое. Предпочтительнее, пожалуй, при малодаровитых 
актерах и плохие постановки. Тогда бы и смеялись больше» [11, c. 40].

Н.Н. Сапунов был всегда полон увлекательных замыслов. Весной 1912 г. он принимал участие в организации нового театра в Териоках, для которого мечтал написать декорации к «Грозе» А.Н. Островского [6, с. 4]. Известно, что он намеревался летом того же года поехать в Париж, по-видимому, в надежде получить постановку в русской антрепризе С.П. Дягилева. Но его замыслам не суждено было сбыться. 14 (27) июня 1912 г. в белую ночь Н.Н. Сапунов с небольшой компанией молодежи отправился кататься на лодке около Териок, под Петербургом. От неловкого движения одного из участников поездки лодка перевернулась и Н.Н. Сапунов, не умевший плавать, стал тонуть. Спасти его, к сожалению, не удалось. Трагическая гибель Н.Н. Сапунова, одного из интересных русских художников предреволюционной поры, глубокой скорбью отозвалась в сердцах всех, кому было дорого родное искусство. А.Н. Бенуа писал в те дни: «Смерть похитила чудесного нашего живописца Н.Н. Сапунова, самого подлинного колориста среди русских художников, волшебника, заставлявшего краски звучать и петь в чарующей музыкальности» [6, с. 4]. До настоящего времени живопись Н.Н. Сапунова привлекает своей красотой и изысканностью.

Выводы. Таким образом, осуществляя на сцене вместе с другими творцами спектакля синтез искусств, к которому стремилась художественная общественность на рубеже XIX и XX вв., Н.Н. Сапунов прекрасно понимал, что на подмостках сцены этот синтез не долговечен, что он существует, пока идет спектакль, и таким образом попытался увековечить то, что являлось плодом его совместной работы с режиссером и актерами. Преданность театру особенно окрепла благодаря совместной работе художника с В.Э. Мейерхольдом и Ф.Ф. Комиссаржевским, новаторские идеи которых находили у него горячий отклик. Редкий живописный дар в Н.Н. Сапунове раскрылся с наибольшей полнотой в его театральных работах, осуществленных вместе с В.Э. Мейерхольдом, а также в его 
пейзажах и этюдах. Его блистательные по живописи и яркой театральности декорации и костюмы для «Мещанинадворянина» Мольера и «Принцессы Турандот» в постановках Ф.Ф. Комиссаржевского в Петербурге и в Москве существенно не выявляют новых черт его творчества, которое безвременно оборвалось в связи с его смертью в 1912 году [13, с. 292]. Анализ творчества крупнейших режиссеров-новаторов, Ф.Ф. Комиссаржевского, В.Э. Мейерхольда и К.С. Станиславского, с которыми Н.Н. Сапунов плодотворно сотрудничал, а также их главных помощников, может послужить перспективами дальнейших исследований в данном направлении. Именно они стремились распространить гротеск на суть театра вообще, но эта суть была уловлена весьма проницательно. Ведь и К.С. Станиславского, принципиально чуждого гротескной методологии (несмотря на старания его последователей приписать ему гротеск), постоянно мучил вопрос о природной двойственности актерского творчества и пресловутое «я - не я» волновало его ничуть не меньше, чем В.Э. Мейерхольда, находясь на стороне которого легко было поставить знак равенства не только между модерном и гротеском, но и между модерном и театром.

\section{Список использованной литературы:}

1. Автобиографии, списки произведений П.В. Кузнецова и выставок с его участием [1934]-1967 гг. РГАЛИ. Ф. 2714. Оп. 1. Ед. хр. 93. Л. 27.

2. Алпатов М.В. Николай Николаевич Сапунов [18801912]. Москва: Искусство, 1965. 48 с.

3. Бальмонт К.Д. Голубая роза. Стихотворения; Вступ. ст., с. 3-20, и сост. Л. Озерова; Худож. В. Серебряков]. Москва: Художественная литература, 1990. Сс. 152-153.

4. Бенуа А.Н. Художественные итоги. Ежегодник газеты «Речь» на 1913 г. Санкт-Петербург, 1913. Сс. 409-417.

5. Гофман И.М. Николай Сапунов = Nikolai Sapunov: монография. Москва: Новости, 2003. 481 с. 
6. Гунст Е.А. Сапунов Н.Н. (вступ. ст.). Москва: Изобразительное искусство, 1974. 4 с.

7. Давыдова М.В. Очерки истории русского театральнодекорационного искусства XVIII - начала XX века. Москва: Наука, 1974. 188 с.

8. Коган Д.З. Николай Николаевич Сапунов: 1880-1912. Москва: Искусство, 1998. 188 с.

9. Комиссаржевский Ф.Ф. Я и театр: Мемуары, дневники, письма. Москва: Искусство, 1999. 277 с.

10. Константин Коровин: жизнь и творчество. Письма. Документы. Воспоминания. Сост. книги, авт. моногр. очерка Н.М. Молева. Москва: Издательство Академии художеств CCCP, 1963. 563 c.

11. Николай Сапунов: Альбом. Москва: Белый город, 2002. $47 \mathrm{c}$.

12. Обри Бердслей (Окончание) (Н. Сапунов. Зима. Передвижная выставка). Мир искусства. 1900. №9-10. С. 114.

13. Пожарская М.Н. Русское театрально-декорационное искусство конца XIX - начала XX века. Москва: Искусство, $1970.410 \mathrm{c}$.

14. Сапунов Н.Н. Письма [черновики] к В.Э. Мейерхольду, Ф.Ф. Комиссаржевскому, М.А. Кузмину и другим лицам: тетрадь 1907 года. ОР ГТГ. Ф. 98. Ед. хр. 127. Л. 21 об.

15. Филиппова О.Н. Натюрморт в творчестве Николая Сапунова. Искусство Евразии. 2019. №1(12). Сс. 26-39.

16. Филиппова О.Н. Творчество Н.Н. Сапунова/ Ломоносовские чтения. Актуальные вопросы фундаментальных и прикладных исследований: сб. ст. VI Международной научнопрактической конференции (15 апреля 2021 года). Петрозаводск: МЦНП «Новая наука», 2021. Сс. 195-202. 
Ольга Миколаївна Філіппова, завідуюча архівом, Політехнічний музей,

Москва, Росія, e-mail: iscusstvo0891@mail.ru, ORCID: 0000-0002-8933-1214

\section{ЖИВОПИСНИЙ ДАР МИКОЛИ САПУНОВА I TEATP}

Анотація. Студія на Поварській (Театр-студія на Поварській), що виникла при Московському Художньому театрі, була створена в травні 1905 р. зусиллями одного з його керівників, К.С. Станіславського, і актором В.Е. Мейєрхольдом. М.М. Сапунов, як не можна більше, був доречний у новій студії, яка подобалася йому своїми постановочними ідеями і планами, наміченим репертуаром, в якому головна роль відводилася драматургам - неоромантикам і символістам, пошуками нових форм для його сценічного здійснення, прагненням до створення нових принципів театрального мистецтва. Після закриття студії у жовтні того ж року, В.Е. Мейєрхольд отримав запрошення від В.Ф. Коміссаржевської працювати в ії театрі, який став центром тяжіння нових сил російської культури. Ця пропозиція була прийнята режисером. В.Ф. Коміссаржевську та В.Е. Мейєрхольда об'єднувало величезне бажання припинити зі сценічним побутовізмом і натуралізмом, знайти нові театральні форми. Такому майстру, як В.Е. Мейєрхольд, що володів дивовижним даром зорово-пластичного бачення вистави, потрібна була на сцені виразність справжнього живопису. У театр В.Ф. Коміссаржевської він залучив молодих художників, М.М. Сапунова, С. Ю. Судейкіна, Б.І. Анісфельда, що не належав до цього кола, але був близький йому, B.I. Денисова. Талановиті живописці, ці молоді майстри були недосвідчені в питаннях сценічної техніки, вирішення просторових завдань. Але це i не було потрібно В.Е. Мейсрхольду. Він звільнив декораторів від кропіткої i ретельної роботи з макетом і орієнтував їх на вирішення вистави 
в чисто живописному плані. У мейєрхольдовскій період, який тривав з 1906 по 1907-i pp., у театрі В.Ф. Коміссаржевської провідними художниками були нерозлучні друзі М.М. Сапунов і С.Ю. Судейкін - учні К.О. Коровіна. В їх сценічному живописі виникали образи символістської поетики з ії недомовленістю, туманними мріями і примарною мрійливістю. Вона ставала невагомою, повітряно легкою або декоративно гострою, збудливою, побудованою на несподіваних поєднаннях вишуканих колористичних співзвуч кольору. У даній публікації автор, грунтуючись на вивченні архівних і бібліографічних джерел, аналізує живопис М.М. Сапунова, який вражає своєю дивовижною красою і гармонією, непозбувною декоративною фантазією. Майстер був здатний, пішовши від натури, перетворювати все видиме, - природу, предмети, - на світ краси, хвилюючої, привабливої, одухотвореної і часом таємничої. Простежується творчий шлях М.М. Сапунова, в таланті якого 3 його невичерпною декоративністю В.Е. Мейєрхольд розпізнав ще одну особливість обдарування майстра - гостру іронічність гротескного бачення.

Ключові слова: майстерня, живописне обдарування, пейзаж, етюд, журнал, автобіографія, символізм, модерн, виставки, театральні декорації та костюми

\section{Olga N. FILIPPOVA,}

Head of the Department of the Polytechnic Museum,

Moscow, Russia, e-mail: iscusstvo0891@mail.ru,

ORCID: 0000-0002-8933-1214

\section{THE PICTURESQUE GIFT OF NIKOLAI SAPUNOV AND THE THEATER}

Abstract. The Studio on Povarskaya (Studio Theater on Povarskaya), which originated at the Moscow Art Theater, was created in May 1905 by the efforts of one of its leaders, K.S. Stanislavsky, and actor V.E. Meyerhold. N.N. Sapunov was 160 
appropriate in the new Studio, most of all, which he liked for its staged ideas and plans, the planned repertoire, in which the main role was assigned to playwrights - neo-romantics and symbolists, the search for new forms for its stage implementation, the desire to create new principles of theatrical art.

After the studio closed in October of the same year, V.E. Meyerhold received an invitation from V.F. Komissarzhevskaya to work in her theater, which became the center of attraction of new forces of Russian culture. This proposal was accepted by the director. V.F. Komissarzhevskaya and V.E. Meyerhold were united by a great desire to get rid of stage everyday life and naturalism, to find new theatrical forms. Such a master as V.E. Meyerhold, who had an amazing gift of visual and plastic vision of the performance, needed the expressiveness of real painting on the stage. He attracted young artists to the theater of V.F. Komissarzhevskaya, N.N. Sapunov, S.Y. Sudeikin, B.I. Anisfeld, and V.I. Denisov, who did not belong to this circle, but was close to them. Talented painters, these young masters were inexperienced in matters of stage technique, solving spatial problems. But this was not required by V.E. Meyerhold. He freed the decorators from painstaking and careful work with the layout and guided them to solve the performance in a purely pictorial plan. During the Meyerhold period in the theater of V.F. Komissarzhevskaya, which lasted from 1906 to 1907, the leading artists were inseparable friends N.N. Sapunov and S.Y. Sudeikin as an students of K.A. Korovin. In their stage painting, images of symbolist poetics appeared with its understatement, foggy dreams and ghostly dreaminess. It became weightless, airily light or decoratively sharp, exciting, built on unexpected combinations of exquisite coloristic consonances of color. In this publication, the author, as a result of studying archival and bibliographic sources, analyzes the painting of N.N. Sapunov, which impresses with its amazing beauty and harmony, inescapable decorative fantasy. The master was able, having left nature, to transform everything visible: nature, objects-into a world of beauty, exciting, alluring, animated and sometimes mysterious. The author traces the creative path of 
N.N. Sapunov, in whose talent, with its inexhaustible decorativeness, V.E. Meyerhold recognized another feature of the master's talent the acute irony of grotesque vision.

Key words: Workshop, a picturesque talent, landscape, etude, journal, autobiography, symbolism, modern, exhibitions, theater sets and costumes

\section{References:}

1. Avtobiografii, spiski proizvedenij P.V. Kuznetsova i vystavok s ego uchastiem [1934]-1967 gg. [Autobiographies, lists of works by P.V. Kuznetsov and exhibitions with his participation [1934]-1967 gg.]. RGALI. F. 2714. Op. 1. Ed. hr. 93. L. 27 [in Russian]

2. Alpatov, M.V. (1965). Nikolaj Nikolaevich Sapunov [18801912] [Nikolai Nikolaevich Sapunov [1880-1912]. Moscow: Iskusstvo [in Russian]

3. Bal'mont, K.D. (1990). Golubaja roza. Stihotvorenija [Blue Rose. Poems], Moscow: Hudozhestvennaja literature [in Russian]

4. Benua, A.N. (1913). Hudozhestvennye itogi [Artistic results]. Ezhegodnik gazety «Rech'», 409-417 [in Russian]

5. Gofman, I.M. (2003). Nikolaj Sapunov = Nikolai Sapunov: monografija [Nikolai Sapunov $=$ Nikolai Sapunov: monograph], Moscow: Novosti [in Russian]

6. Gunst, E.A. (1974). Sapunov N. N. [Sapunov N. B.] (vstup. st.). Moscow: Izobrazitel'noe iskusstvo [in Russian]

7. Davydova, M.V. (1974). Ocherki istorii russkogo teatral'nodekoratsionnogo iskusstva XVIII - nachala XX veka [Essays on the history of Russian theatrical and decorative art of the XVIII - of the early of the XX century]. Moscow: Nauka [in Russian]

8. Kogan, D.Z. (1998). Nikolaj Nikolaevich Sapunov: 18801912 [Nikolai Nikolaevich Sapunov: 1880-1912]. Moscow: Iskusstvo [in Russian]

9. Komissarzhevskij, F.F. (1999). Ja i teatr: Memuary, dnevniki, pis'ma [Me and the theater: Memoirs, diaries, letters]. Moscow: Iskusstvo [in Russian] 
10. Moleva, N.N. (1963). Konstantin Korovin: zhizn' i tvorchestvo. Pis'ma. Dokumenty. Vospominanija [Konstantin Korovin: life and creative work. Letters. Documents. Memories], Moscow: Publishing House of the Academy of Arts of the USSR [in Russian]

11. Kiselev, M. (2002). Nikolaj Sapunov: Al'bom [Nikolay Sapunov: Album]. Moscow: Belyj gorod [in Russian]

12. Obri Berdslej (okonchanie) (N. Sapunov. Zima. Peredvizhnaja vystavka) [Aubrey Beardsley (Ending) (N. Sapunov. Winter. Traveling exhibition)] (1900). Mir iskusstva, 9-10, 114 [in Russian]

13. Pozharskaja, M.N. (1970). Russkoe teatral'no dekoratsionnoe iskusstvo kontsa XIX - nachala XX veka [Russian theatrical and decorative art of the late XIX - of the early of the XX century]. Moscow: Iskusstvo [in Russian]

14. Sapunov, N.N. Pis'ma [chernoviki] k V.'E. Mejerhol'du, F.F. Komissarzhevskomu, M.A. Kuzminu i drugim litsam: tetrad' 1907 goda [Letters [drafts] to V.E. Meyerhold, F.F. Komissarzhevsky, M.A. Kuzmin and others: a notebook of 1907]. OR GTG. F. 98. Ed. hr. 127. L. 21 vol. [in Russian]

15. Filippova, O.N. (2019). Natjurmort v tvorchestve Nikolaja Sapunova [Still-life in the works of Nikolai Sapunov]. Iskusstvo Evrazii, №1(12), 26-39 [in Russian]

16. Filippova, O.N. (2021). Tvorchestvo N.N. Sapunova [The creative work of N.N. Sapunov]. Lomonosovskie chtenija. Aktual' nye voprosy fundamental'nyh i prikladnyh issledovanij: sbornik statej VI Mezhdunarodnoj nauchno-prakticheskoj konferentsii, 15 aprelja, 195-202 [in Russian] 